\title{
Tissue Deposits of IgA-Binding Streptococcal M Proteins in IgA Nephropathy and Henoch-Schönlein Purpura
}

\author{
Roland Schmitt, ${ }^{*}$ Fredric Carlsson, ${ }^{\dagger}$ \\ Matthias Mörgelin, ${ }^{\ddagger}$ Ramesh Tati, ${ }^{*}$ \\ Gunnar Lindahl, ${ }^{\dagger}$ and Diana Karpman* \\ From the Department of Pediatrics," Clinical Sciences Lund; \\ the Division of Medical Microbiology, ${ }^{\dagger}$ Department of Laboratory \\ Medicine; and the Division of Clinical and Experimental \\ Infection Medicine, ${ }^{\ddagger}$ Clinical Sciences Lund, Lund University, \\ Lund, Sweden
}

IgA nephropathy (IgAN) and Henoch-Schönlein purpura (HSP) are diseases characterized by IgA deposits in the kidney and/or skin. Both may arise after upper respiratory tract infections, but the pathogenic mechanisms governing these diseases remain unclear. $\mathrm{Pa}$ tients with IgAN $(n=16)$ and $\operatorname{HSP}(n=17)$ were included in this study aimed at examining whether IgA-binding M proteins of group A streptococci could be involved. As $M$ proteins vary in sequence, the study focused on the IgA-binding-region (IgA-BR) of three different $M$ proteins: M4, M22, and M60. Renal tissue from IgAN and HSP patients and skin from HSP patients were examined for deposits of streptococcal IgA-BR by immunohistochemistry and electron microscopy using specific antibodies, and a skin sample from a HSP patient was examined by mass spectrometry. IgA-BR deposits were detected in 10/16 IgAN kidneys and 7/13 HSP kidneys. Electron microscopy demonstrated deposits of IgA-BRs in the mesangial matrix and glomerular basement membrane, which colocalized with IgA. Skin samples exhibited IgA-BR deposits in $4 / 5$ biopsies, a result confirmed by mass spectrometry in one patient. IgA-BR deposits were not detected in normal kidney and skin samples. Taken together, these results demonstrate IgA-BR from streptococcal $M$ proteins in patient tissues. IgA-BR, would on gaining access to the circulation, encounter circulatory IgA and form a complex with IgA-Fc that could deposit in tissues and contribute to the pathogenesis of IgAN and HSP. (Am J Pathol 2010, 176:608-618; DOI: 10.2353/ajpath.2010.090428)
Tissue deposits containing IgA characterize $\lg A$ nephropathy (IgAN) and Henoch-Schönlein purpura (HSP), two conditions affecting kidney function. IgAN is the most common primary glomerulonephritis worldwide. Its predominant clinical feature is episodic macroscopic hematuria usually coinciding with upper respiratory tract infections. Symptoms may, however, vary from microscopic hematuria to a severe nephritic-nephrotic syndrome. End-stage kidney disease occurs in $30 \%$ to $40 \%$ of patients within 20 years. Histopathologically IgAN is characterized by mesangial cell proliferation and in progressive cases crescent formation as well as glomerular sclerosis, interstitial fibrosis, and tubular atrophy. Ultramorphologic findings show mesangial deposits of immune complexes containing predominantly $\lg \mathrm{A}^{1,2}$

HSP is the most common form of vasculitis in childhood. It may affect many organs, but usually presents as skin lesions, varying from purpura to bullous intradermal bleedings, arthritis, gastrointestinal involvement with pain and/or bleeding. Renal involvement occurs in up to $50 \%$

Supported by grants from The Swedish Research Council (06X-14008 to D.K. and 06X-09490 to G.L.), the Sven Jerring Foundation, The Fund for Renal Research, Konung Gustav Vs 80-årsfond, Crown Princess Lovisa's Society for Child Care, and the Fanny Ekdahl foundation (all to D.K.); funding from Region Skåne (to R.S. and D.K.); grants from Kristianstad Högskola and the Samariten Foundation (to R.S.); the Foundations of Golje and Lundström and the Royal Physiographic Society in Lund (to F.C.); the Foundations of Kock and Österlund (to G.L.). Diana Karpman is the recipient of a clinical-experimental research fellowship from the Royal Swedish Academy of Sciences.

\section{Accepted for publication September 30, 2009}

This work was presented in part as an oral presentation at the $39^{\text {th }}$ annual meeting of the European Society for Paediatric Nephrology Istanbul, Turkey, September 10-13, 2005 and in poster form at the World Congress of Nephrology Satellite Symposium on IgA Nephropathy, Stresa Italy, May 26-28, 2009.

Current address for F.C.: Department of Microbiology and Tumour Biology, Karolinska Institutet, Stockholm, Sweden.

Address reprint requests to Diana Karpman, M.D., Ph.D., Department of Pediatrics, Clinical Sciences Lund, Lund University, 22185 Lund, Sweden; or Gunnar Lindahl, M.D., Ph.D., Division of Medical Microbiology, Department of Laboratory Medicine, Lund University, Sölvegatan 23, 22362 Lund, Sweden. E-mail: diana.karpman@med.lu.se or gunnar.lindahl@med.lu.se. 
of cases ${ }^{3}$ and is known as Henoch-Schönlein nephropathy (HSN). HSN may manifest as microscopic or macroscopic hematuria as well as glomerulonephritis or nephrotic syndrome. Approximately $20 \%$ of HSN cases will develop renal failure. ${ }^{4}$ The histopathological lesion termed leukocytoclastic vasculitis is characterized by inflammation of small vessels with perivascular polymorphonuclear leukocyte and mononuclear cell infiltrates. Immune deposits in affected organs contain IgA, and renal pathology resembles that seen in IgAN. ${ }^{1,3}$

The IgA mesangial deposits in kidneys of patients with IgAN and HSP are primarily composed of galactosedeficient IgA $1 .{ }^{5-7}$ The mechanism by which under-glycosylated IgA1 deposits in the mesangium, possibly in complex with IgG, ${ }^{8,9}$ has not been determined. Environmental antigens have been proposed to contribute to the disease but have not been consistently associated with mesangial deposits. ${ }^{9}$ Although the etiology of IgAN and HSP is unclear, these diseases are often preceded by infections, primarily of the upper respiratory tract, and an infectious agent has therefore been suspected. There is circumstantial evidence for involvement of group A streptococcus (GAS, Streptococcus pyogenes), ${ }^{10-15}$ but infections with other bacteria ${ }^{16,17}$ as well as viruses ${ }^{18}$ have been implicated as well.

In this study we hypothesized that GAS infection could trigger IgAN and/or HSN, because GAS is a very common cause of upper respiratory tract infection, and because many GAS strains bind IgA-Fc. ${ }^{19-21}$ The ability of a GAS strain to bind human IgA results from the presence of an IgA-binding region (IgA-BR) in the surface-localized M protein. ${ }^{22,23}$ The fibrillar $M$ protein, which is a major virulence factor of GAS, varies in sequence between strains $^{24}$ allowing classification of GAS isolates into more than $120 \mathrm{M}$ serotypes. ${ }^{25}$ The exact function of the IgA-BR in an $\mathrm{M}$ protein is not known, but there is evidence that it contributes to bacterial phagocytosis resistance. ${ }^{26}$ The IgA-BR of an M protein represents a distinct domain that can be studied in isolated form, as a peptide that binds IgA. ${ }^{27,28}$ Such IgA-binding peptides, designated Sap (streptococcal IgA-binding peptide), were used in the experiments described herein.

To analyze whether IgA-binding streptococcal M proteins are present in affected tissues of patients with IgAN and/or HSP, and colocalize with IgA, we used antibodies to the IgA-BR of three different M proteins M4, M22, and M60. Of note, M4 and M22 are among the most common serotypes of clinical GAS isolates. ${ }^{29}$ As the IgA-BRs of different $M$ proteins vary extensively in sequence, ${ }^{22,23}$ the use of antibodies to three different serotypes enhanced our chances to detect tissue deposition of an IgA-BR.

\section{Materials and Methods}

\section{Synthetic Peptides and Rabbit Antisera}

The streptococcal IgA-binding peptides (Sap), designated Sap4, Sap22, and Sap60, are synthetic peptides derived from the M4, M22 and M60 proteins, respectively. ${ }^{22,27}$ These M proteins were earlier designated Arp4, Sir22, and
Arp60, respectively. By focusing the analysis on Sap peptides, rather than on intact $\mathrm{M}$ proteins, we could avoid the problem that many IgA-binding $\mathrm{M}$ proteins have a separate binding site for human IgG-Fc, a property that could complicate experimental conditions. ${ }^{30,31}$

Each Sap peptide has a length of 49 amino acid residues. The Sap4 and Sap22 peptides were derived from amino acids 35 to 83 of M4 and M22, whereas Sap60 was derived from amino acids 44 to 92 of M60. Native Mproteins form dimers but Sap peptides may not do so spontaneously. ${ }^{27}$ A C-terminal cysteine residue, not present in the $\mathrm{M}$ protein, was therefore included in each Sap peptide to promote dimerization via a disulfide-bond and assure the IgA-binding ability of the peptides. ${ }^{27,28}$ The 47-aa residue M4-N peptide corresponds to residues 1 to 45 of the $\mathrm{N}$-terminal of the mature M4 protein, with the C-terminal addition of a tyrosine-cysteine sequence, not present in the M4 protein. ${ }^{32}$ The M5-N peptide was derived from the $\mathrm{N}$-terminal amino acid residues 1 to 50 in the non-IgA-binding M5 protein, with the C-terminal addition of a tyrosine-tyrosine-cysteine sequence. ${ }^{27} \mathrm{M} 5-\mathrm{N}$ was used as a negative control. All peptides were synthesized at the Department of Clinical Chemistry, Lund University, Malmö General Hospital, Sweden.

The specific IgA-binding properties of the Sap peptides immobilized in columns were tested using human serum applied to HiTrap columns (Amersham Bioscience, Uppsala, Sweden) containing the immobilized Sap peptides. Bound protein was eluted with acetate buffer $\mathrm{pH}$ 4.0. Normal human serum and the eluates were analyzed by SDS-PAGE. IgA heavy chains $(\mathrm{H})$ and light chains $(L)$ were identified by immunoblotting using specific antibodies as previously described. ${ }^{27}$

Rabbit antisera against dimerized Sap peptides were raised as described. ${ }^{32}$ IgG fractions of the rabbit antiSap sera were further purified on a Protein A-Sepharose column (Amersham Biosciences) for tissue studies. Antigenic properties and cross-reactivity between different Sap peptides was analyzed using rabbit antisera and Sap peptides immobilized in microtiter wells as described. ${ }^{32}$ The anti-Sap4 antiserum had a lower titer than the anti-Sap22 and anti-Sap60 antisera. The anti-Sap4 antibodies were therefore concentrated and purified by applying the serum to a Sap4 column. ${ }^{26}$

The anti-Sap antisera generated in rabbits would be expected to react with Sap but not with human IgA. Cross reactivity of the IgG-fractions of the anti-Sap sera with IgA was ruled out by ELISA using microtiter wells (Maxisorp, Nunc, Roskilde, Denmark) coated with normal human IgA (5 $\mu \mathrm{g} / \mathrm{ml}$, Sigma Aldrich, St. Louis, MO), probed with rabbit-anti-Sap-lgG (anti-Sap4 $0.45 \mu \mathrm{g} / \mathrm{ml}$, anti-Sap22 $2.8 \mu \mathrm{g} / \mathrm{ml}$, anti-Sap60 $2.35 \mu \mathrm{g} / \mathrm{ml}$, final concentrations). Bound antibodies were detected with goat anti-rabbit$\operatorname{HRP}(0.3 \mu \mathrm{g} / \mathrm{ml}$, Dako Cytomation, Carpinteria, CA $)$ at OD $490 \mathrm{~nm}$. Furthermore, the interaction was tested by Western blot under nonreducing conditions using normal human sera $(n=8$, diluted $1 / 100[\mathrm{v} / \mathrm{v}])$ in sample buffer (3.2\% [w/v] sodium dodecyl sulfate [Bio Rad, Hercules, CA], 8\% glycerol [Sigma-Aldrich], 1\% bromophenol blue [LKB Products AB, Bromma, Sweden] in $0.01 \mathrm{~mol} / \mathrm{L}$ Tris buffer, pH 6.8 [ICN Biomedicals, Aurora, $\mathrm{OH}]$ ) probed 
with rabbit anti-Sap-lgG (anti-Sap4 $0.9 \mu \mathrm{g} / \mathrm{ml}$, anti-Sap22 $3.7 \mu \mathrm{g} / \mathrm{ml}$, anti-Sap60 $9.4 \mu \mathrm{g} / \mathrm{ml})$. Sap peptides $(0.1 \mathrm{mg} /$ $\mathrm{ml}$ ) in control-serum or PBS were used as positive controls. Bound antibodies were detected with goat antirabbit-HRP $(0.15 \mu \mathrm{g} / \mathrm{ml})$. The anti-Sap-lgG did not bind to IgA using both of the methods, and in Western blot the anti-Sap did not react with any serum protein.

\section{Subjects}

Patients with IgAN ( $n=16,3$ girls and 13 boys, median age 12.5 years, range: 3 to 19 years $)$ and $\operatorname{HSP}(n=17$, 7 girls, 10 boys, median age 13 years, range 7 to 18 years) treated at the Department of Pediatrics, Lund University, between 1994 and 2008 were included in the study. IgAN was defined as the presence of hematuria and/or glomerulonephritis with or without proteinuria in patients in whom renal biopsy showed mesangioproliferative glomerulonephritis with immune deposits of IgA in glomerular mesangial cells and matrix. HSP was defined as per the criteria of the American College of Rheumatology. ${ }^{33}$ Thirteen of the 17 HSP patients had nephropathy (HSN) manifesting as the occurrence of hematuria and proteinuria. The high proportion of HSN in patients treated for HSP reflects the clinical spectrum of patients referred to a tertiary center.

Clinically relevant data at the time of biopsy were obtained from the patients' hospital charts. Data regarding proteinuria, serum creatinine levels, as well as biopsy findings such as the presence of crescents, mesangial IgG deposits and tubulo-interstitial affection, were recorded. Proteinuria was measured by one of the following methods: albumin/creatinine clearance assayed using Hitachi Modular-P (Roche Diagnostics Scandinavia AB, Bromma, Sweden), urine albumin/creatinine index, quantified using Hitachi Modular-P, or by total quantitation of 24-hour urine albumin secretion. All analyses were performed by accredited hospital laboratories.

\section{Microbiological Investigation of Patients}

Evidence for GAS infection was investigated by microbiological (throat culture at time of onset) or serological methods. Anti-streptolysin O and/or anti-DNase B were assayed at routine hospital laboratories using kits from BioSystem S.A., Barcelona, Spain (anti-streptolysin O) and Dade Behring, Deerfield, IL, USA (anti-DNase B) in serum samples obtained within 0 to 17 months, median 1.5 months, after clinical debut of IgAN or HSP.

Three patients with IgAN had positive serology, and three had a positive throat culture for GAS. Two of these GAS isolates were saved. Thus 6/16 IgAN patients $(37.5 \%)$ had evidence of recent streptococcal infection. Likewise, two patients with HSP had positive serology and one had a positive GAS throat culture; altogether 3/17 patients with HSP (17.6\%) had evidence for recent streptococcal infection. The two GAS isolates taken from patients with newly diagnosed IgAN were obtained during an episode of acute pharyngitis with onset of macro- scopic hematuria. These strains were of serotype M4 as determined by DNA sequencing. ${ }^{34}$

\section{Tissue and Blood Samples}

Renal biopsies were available from all patients with IgAN $(n=16)$. Biopsies that had been paraffin-embedded and saved at the Department of Pathology were used. Glomeruli were detected in all biopsies after routine diagnostics was completed. Crescent formation was found in nine biopsies and tubulo-interstitial affection (tubular atrophy, interstitial inflammation, and fibrosis) in eight biopsies. Biopsies were obtained at a median of eight months after the onset of disease (range, 2 to 72 months). The 16 biopsies used for immunohistological investigation had a median of 5 glomeruli (range, 1 to 24), a total of 76 glomeruli were detected. Renal biopsy was performed in $13 / 13 \mathrm{HSN}$ cases within a median of 4 months after clinical debut of HSP (range, 0 to 60 months). Glomeruli were detected in all of the biopsies and showed mesangioproliferative glomerulonephritis with immune deposits of IgA in the glomerular pericapillary and mesangial regions. Crescents were noted in 8/13 biopsies and tubulo-interstitial affection in 5/13. The 13 biopsies used for immunohistological investigation had a median of 4 glomeruli (range, 1 to 13), a total of 80 glomeruli were detected. Skin biopsies were performed in five HSP cases during the acute stage of the disease and showed leukocytoclastic vasculitis, with pericapillary deposits containing IgA. Two of these five patients with HSP developed nephropathy. For one patient both a skin and a kidney sample were available.

Renal tissue from disease controls was chosen from individuals diagnosed with conditions other than IgAN and HSN whose renal biopsies showed glomerular IgA deposits. Disease control renal biopsies were available from 10 patients with: SLE-nephritis $(n=4$, median age 12 years, range 8 to 16 years), membranous glomerulonephritis ( $n=4$, median age 49 years, range 10 to 65 years), Goodpasture's disease ( $n=1$, age 65 years), and poststreptococcal glomerulonephritis $(n=1$, age 52 years). Normal renal tissue was available from three patients. One kidney biopsy, obtained from a 10-year-old girl as part of investigation of hematuria, was deemed normal by the hospital pathologist. Two kidney samples were obtained from nephrectomized kidneys of two adults (one female and one male) with renal cancer who had not received any chemo- or radiotherapy before surgery. Tissue was taken from an area unaffected by cancer and evaluated as normal by the hospital pathologist. Two histologically normal skin resection biopsies taken from unidentified adults with breast cancer were available.

Blood (serum or citrated plasma) samples, taken within a median of three months after onset of clinical disease (as defined by the presence of symptoms, range 1 to 13 months) and a median of 0 months before biopsy (range 0 to 2 months), were available from 12 patients (IgAN: $n=7$, HSP: $n=5$ ). Control blood samples were obtained from five healthy adults. Venous blood was collected in 
4-ml vacutainer Hemogard SST tubes for serum or in 5-ml vacutainer tubes, containing $0.5 \mathrm{ml} 0.129 \mathrm{~mol} / \mathrm{L}$ sodium citrate for plasma (tubes from Becton Dickinson, Plymouth, UK). Samples were centrifuged at $2000 \mathrm{~g}$ for 10 minutes and frozen at $-20^{\circ} \mathrm{C}$ until assayed.

The study (patients and controls) was approved by the ethics committee of the Medical faculty of Lund University, and samples were obtained with written informed consent of all patients and controls, or the parents when patients were younger than 15 years.

\section{Immunohistochemistry of the Kidney and Skin Biopsies}

Immunohistochemsitry was performed on deparaffinized tissue sections as previously described ${ }^{35}$ with certain modifications. Briefly, endogenous peroxidase activity was blocked by incubation in 10\% methanol and $3 \%$ $\mathrm{H}_{2} \mathrm{O}_{2}(\mathrm{v} / \mathrm{V})$ for 25 minutes at room temperature, and unspecific binding sites were blocked by incubation with normal goat serum (Dako, Glostrup, Denmark, 1/70 [v/v]). Detection of IgA-BR was performed using rabbit antiSap IgG (on renal tissue: anti-Sap4 $0.38 \mu \mathrm{g} / \mathrm{ml}$, affinitypurified anti-Sap4 $0.06 \mu \mathrm{g} / \mathrm{ml}$, anti-Sap22 $0.7 \mu \mathrm{g} / \mathrm{ml}$, anti-Sap60 $0.39 \mu \mathrm{g} / \mathrm{ml}$; on skin tissue: anti-Sap4 0.25 $\mu \mathrm{g} / \mathrm{ml}$, anti-Sap22 $1.4 \mu \mathrm{g} / \mathrm{ml}$, anti-Sap60 $0.39 \mu \mathrm{g} / \mathrm{ml}$ ) in $2.5 \%$ bovine serum albumin (BSA, MP Biomedicals Irvine, CA), $5 \mathrm{mmol} / \mathrm{L}$ Tris (Sigma-Aldrich), $0.9 \% \mathrm{NaCl}$ (Scharlau Chemie SA), pH 7.6. Similarly, tissues were labeled with rabbit anti-M4-N (N-terminal of the M4 protein) at $0.14 \mu \mathrm{g} / \mathrm{ml}$. As the secondary antibody peroxidase-conjugated goat anti-rabbit antibody (Envision $^{+}$-system, DakoCytomation) was used. Positive staining labeled brown.

Antibody specificity was tested by using either preimmune rabbit sera IgG in equimolar amounts to the antiSap, or by anti-Sap preincubated with a molar excess $(20: 1)$ of the specific Sap antigen for 1 hour at $37^{\circ} \mathrm{C}$. Specificity of the secondary antibody system was tested by omitting the primary antibody. Slides were examined by light microscopy (Axiostar Zeiss, mounted with AxioCam MRc5 camera, Carl Zeiss AB, Stockholm, Sweden). AxioVision AC software version 4.4 (Carl Zeiss AB) was used for image processing.

\section{Electron Microscopy}

Kidney samples were sectioned and prepared for transmission electron microscopy as previously described. ${ }^{36}$ Detection of IgA-BR was performed using rabbit antiSap60 lgG at a final concentration of $4.7 \mu \mathrm{g} / \mathrm{ml}$ or antiSap4 at $4.5 \mu \mathrm{g} / \mathrm{ml}$ in incubation buffer: $0.5 \%$ BSA, $0.1 \%$ gelatin (BioRad, Richmond, CA), 20 mmol/L NaN3 (Sigma Aldrich) in PBS. For detection of IgA monoclonal mouse anti-human IgA (2 $\mu \mathrm{g} / \mathrm{ml}$ in incubation buffer, Dako) was used. Tissue sections were incubated with the primary antibody at $4^{\circ} \mathrm{C}$ overnight. The secondary antibody was goat anti-rabbit IgG:gold $10 \mathrm{~nm}$ (for the Sap antibody) or goat anti-mouse IgG:gold $6 \mathrm{~nm}$ (for the IgA antibody, Aurion, Washington, PA) diluted 1/20 (v/v) in incubation buffer. Grids were examined as described. ${ }^{37}$ Adobe Photoshop 7.0 (Adobe Systems, San Jose, CA) was used for image processing. Gold particles ( 6 and $10 \mathrm{~nm}$ ) were considered to be associated if their proximity was $30 \mathrm{~nm}$ or less as each conjugated IgG molecule is $15 \mathrm{~nm}^{38,39}$

Specificity of the anti-Sap antibodies was tested by preincubating with the specific Sap antigen (molar excess of Sap 28:1). For the anti-IgA-antibody normal mouse-lgG $\mathrm{G}_{1}$ (Dako) was used as the negative control. Specificity of the secondary antibody was tested by omission of the primary antibody.

\section{ELISA for Detection of Complexes between IgA-BR and IgA in Blood Samples}

ELISA microtiter wells (Maxisorp) were coated with the IgG-fraction of polyclonal rabbit anti-Sap4 $(0.09 \mu \mathrm{g} / \mathrm{ml})$, anti-Sap22 $(0.18 \mu \mathrm{g} / \mathrm{ml})$, or anti-Sap60 $(0.10 \mu \mathrm{g} / \mathrm{ml})$ followed by patient or control sera $(1 / 100[\mathrm{v} / \mathrm{v}])$ in phosphate-buffered saline-Tween 0.05\% (Medicago, Uppsala, Sweden) containing $0.1 \%$ BSA. As a positive control normal serum, to which IgA-BR (from M4, M22 or M60) 50 $\mu \mathrm{g} / \mathrm{ml}$ was added, was used. To detect IgA bound to IgA-BR in serum, rabbit anti-human IgA-HRP $(0.32 \mu \mathrm{g} / \mathrm{ml}$, DakoCytomation) was added. Detection was performed at OD $490 \mathrm{~nm}$.

\section{Selected Reaction Monitoring Mass Spectrometry}

Selected reaction monitoring mass spectrometry ${ }^{40}$ was used to detect the presence of IgA-BR in skin. An ample skin sample from one patient with HSP was assayed for the presence of IgA-BR from M22 and compared with skin samples from the two controls.

Deparaffinized skin samples were suspended in lysis buffer consisting of $8 \mathrm{~mol} / \mathrm{L}$ urea (Sigma-Aldrich, Steinheim, Germany), $30 \mathrm{mmol} / \mathrm{L}$ Tris (Fluka Chemie $\mathrm{GmbH}$, Buchs, Switzerland), $5 \mathrm{mmol} / \mathrm{L} \mathrm{MgAc}$ (Sigma-Aldrich), $\mathrm{pH}$ 8.5, ground with a grinding-pestle, sonicated, vortexed, and centrifuged at $14,000 \mathrm{rpm}$ for 10 minutes. The supernatant was diluted fourfold with sterile $\mathrm{H}_{2} \mathrm{O}$ to reduce the urea concentration. Sap22 (15 pmol/ $\mu \mathrm{l})$ in $0.1 \%$ formic acid (JT Baker, Tamro, Mölndal, Sweden) was used as the positive control. Human plasma samples with or without added Sap22, at concentrations of $1.5 \mathrm{pmol} / \mu \mathrm{l}$ to $0.25 \mathrm{fmol} / \mu \mathrm{l}$, were also used as detection controls.

All samples were adjusted to equivalent protein amounts using the Bicinchoninic Acid Assay Kit (Pierce, Rockford, $\mathrm{IL}$ ) and a $\mathrm{pH}$ of 8.5. Samples were reduced with 45 $\mathrm{mmol} / \mathrm{L}$ dithiothreitol (Sigma-Aldrich) for 15 minutes at $50^{\circ} \mathrm{C}$ and after cooling to room temperature underwent alkylation using $100 \mathrm{mmol} / \mathrm{L}$ iodoacetic acid (SigmaAldrich) for 15 minutes in the dark at room temperature. The proteins were then digested by adding 1/25 (w/w) bovine trypsin (Sigma-Aldrich) overnight at $37^{\circ} \mathrm{C}$. Digestion was terminated by addition of $88 \%$ formic acid. Samples were stored at $-20^{\circ} \mathrm{C}$ until analyzed. 
A

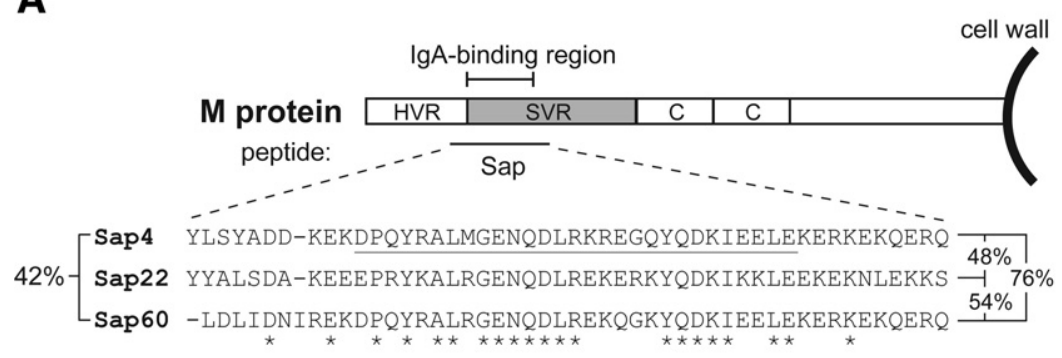

B

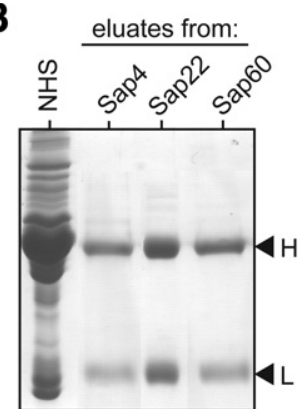

C
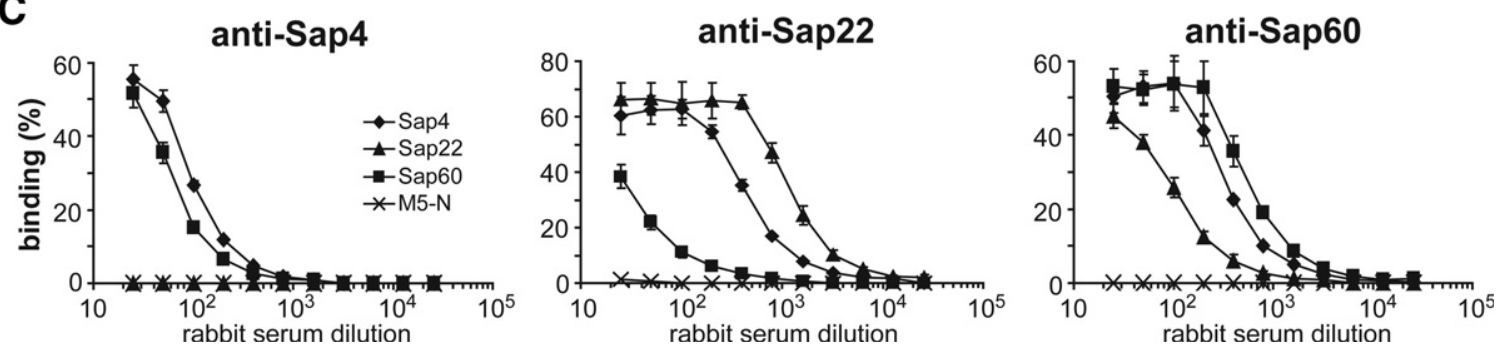

Figure 1. Characterization of the IgA-binding region of three streptococcal $M$ proteins. A: Location and sequence of IgA-binding regions. The M protein is covalently attached to the bacterial cell wall and includes an N-terminal hypervariable region, a semivariable region, and a relatively conserved C-repeat region. Many M proteins have an IgA-binding region, as indicated. Synthetic peptides that include this region are designated Sap. The alignment shows the sequences of Sap4, Sap22, and Sap60 (derived from the M4, M22, and M60 proteins, respectively). The 29-residue sequence underlined in Sap4 represents the shortest region known to confer IgA-binding ability in an intact M protein. ${ }^{22}$ Asterisks indicate residues identical in all three Sap peptides. Residue identity (\%) for all three peptides is indicated to the left and pair-wise identities (\%) are shown to the right. B: Sap peptides specifically bind IgA. Normal human serum (NHS) was applied to columns containing different immobilized Sap peptides. Proteins bound were eluted and analyzed by SDS-PAGE under reducing conditions, using NHS as a control. Arrowheads indicate the position of IgA heavy chains $(\mathbf{H})$ and light chains (L). C: Antigenic cross-reactivity among Sap peptides. The three Sap peptides, and the control non-IgA binding peptide M5-N, were immobilized in microtiter wells and analyzed for capacity to bind rabbit antibodies directed against Sap peptides, as indicated. Data from three experiments with duplicate samples are presented as means \pm SD.

Each sample (1.5 pmol) was loaded onto a trap column (Zorbax 300SB-C18, $5 \mu \mathrm{m}, 5 \times 0.3 \mathrm{~mm}$ ) and separated on a Zorbax 300SB-C18 $3.5 \mu \mathrm{m}, 150 \mathrm{~mm} \times 75 \mu \mathrm{m}$ using an Agilent 1100 series capillary and nanopump 2D-separation system (Agilent Technologies, Santa Clara, CA). The peptides were eluted using a binary solvent system. Analysis was performed using a triple quadrupole mass spectrometer ThermoFinnigan TSQ Quantum (Thermo Finnigan, San Jose, CA) equipped with a nanospray source and a metallic emitter (Proxeon Biosystems A/S, Odense, Denmark).

Based on the known preference of trypsin for lysine or arginine residues and the sequence of the IgA-BR of the M22 protein (Figure 1A) six plausible cleavage products were predicted. Analysis of trypsin-digested Sap22 and Sap22-spiked plasma showed that only one predicted cleavage product, the peptide ALRGENQDLR (mass $1171 \mathrm{Da}$, mass/charge $[\mathrm{m} / \mathrm{z}]$ ratio $586[\mathrm{M} 2 \mathrm{H}+])$, displayed a distinct peak (defined as more than threefold the background signal). This peak was eluted at 32.97 minutes. In normal human plasma it was not detected. A Blast Search with the UniProtKB release 13.2 database using NCBI BLASTP 2.2.17 showed that the analyzed peptide sequence does not occur in any known human protein, but exclusively in M-proteins of certain IgA binding GAS serotypes. Further experiments analyzed the predicted breakage of the filtered parent peptide specifically after Asp (D) and Asn (N) during passage through the collision cell and therefore transition of the $\mathrm{m} / \mathrm{z}$ ratio from 586 to 884 and 641 in the daughter fragments.

\section{Statistics}

Statistical evaluation was performed using SPSS version 14.0 (Chicago, IL). The correlation between clinical/ pathological features and IgA-BR-deposits was analyzed using the Fisher exact test. $P$ values $<0.05$ were considered significant.

\section{Results \\ Characterization of the IgA-Binding Region in Different M Proteins}

The studies reported here used the M4, M22, and M60 proteins, which bind human IgA-Fc. ${ }^{20,30,31}$ The IgA-BRs of the three $\mathrm{M}$ proteins were characterized in isolated form, as synthetic peptides designated Sap4, Sap22, and Sap60, respectively (Figure 1A). Overall, these three peptides show $42 \%$ amino acid residue identity. Affinity chromatography of whole human serum on immobilized Sap peptides showed that each peptide specifically binds IgA among all proteins in serum (Figure 1B). Thus, all three Sap peptides retained the properties of the IgA-BR of the corresponding intact $\mathrm{M}$ protein, implying that these peptides could be used for immunological comparisons of the IgA-BRs.

To compare the antigenic properties of the three Sap peptides, we used rabbit antisera and peptides immobilized in microtiter wells (Figure 1C). As expected, this analysis showed that the Sap peptides have different antigenic 
Table 1. IgA-BR in Tissue Samples from Patients with IgAN and HSP

\begin{tabular}{|c|c|c|c|c|c|c|c|c|}
\hline & \multicolumn{2}{|c|}{$\lg \mathrm{A}-\mathrm{BR}$ of $\mathrm{M} 4$} & \multicolumn{2}{|c|}{ IgA-BR of M22 } & \multicolumn{2}{|c|}{ IgA-BR of M60 } & \multicolumn{2}{|c|}{ Total } \\
\hline & $\begin{array}{c}\text { No. of } \\
\text { positive } \\
\text { samples/total }\end{array}$ & $\begin{array}{c}\text { No. of labeled } \\
\text { glomeruli/total } \\
\text { in positive } \\
\text { samples (\%) }\end{array}$ & $\begin{array}{c}\text { No. of } \\
\text { positive } \\
\text { samples/total }\end{array}$ & $\begin{array}{l}\text { No. of labeled } \\
\text { glomeruli/total } \\
\text { in positive } \\
\text { samples (\%) }\end{array}$ & $\begin{array}{c}\text { No. of } \\
\text { positive } \\
\text { samples/total }\end{array}$ & $\begin{array}{l}\text { No. of labeled } \\
\text { glomeruli/total } \\
\text { in positive } \\
\text { samples (\%) }\end{array}$ & $\begin{array}{c}\text { No. of } \\
\text { positive } \\
\text { samples/total }\end{array}$ & $\begin{array}{l}\text { No. of labeled } \\
\text { glomeruli/total } \\
\text { in positive } \\
\text { samples (\%) }\end{array}$ \\
\hline $\begin{array}{l}\text { IgAN } \\
\text { (kidney) }\end{array}$ & $7 / 16^{*}$ & 17/44 (39\%) & $0 / 16$ & - & $6 / 16$ & $50 / 68$ (74\%) & $10 / 16^{+}$ & $67 / 112(60 \%)$ \\
\hline $\begin{array}{l}\text { HSN } \\
\text { (kidney) }\end{array}$ & $4 / 13^{*}$ & $12 / 26(46 \%)$ & $2 / 13$ & $12 / 12(100 \%)$ & $6 / 12$ & 23/43 (53\%) & $7 / 13^{+}$ & $47 / 81(58 \%)$ \\
\hline $\begin{array}{l}\text { Total } \\
\text { HSP (skin) }\end{array}$ & $\begin{array}{l}11 / 29^{\ddagger} \\
0 / 5\end{array}$ & $\begin{array}{c}29 / 70(41 \%) \\
-\end{array}$ & $\begin{array}{l}2 / 29 \\
2 / 5\end{array}$ & $\begin{array}{c}12 / 12(100 \%) \\
-\end{array}$ & $\begin{array}{l}12 / 28^{\ddagger} \\
2 / 5\end{array}$ & $\begin{array}{c}\text { 73/111 (66\%) } \\
-\end{array}$ & $\begin{array}{l}17 / 29^{\dagger} \\
4 / 5\end{array}$ & $\begin{array}{c}114 / 193(59 \%) \\
-\end{array}$ \\
\hline
\end{tabular}

${ }^{*}$ Immunohistochemistry with polyclonal rabbit anti-Sap4 IgG showed positive glomerular staining in one patient with IgAN and three with HSN. Using affinity-purified anti-Sap4 IgG antibodies, positive staining was identified in an additional six patients with IgAN and one with HSN.

†Labeling with more than one antibody in the same sample occurred in some patients: with all three antibodies in two patients with HSN, and with two antibodies (anti-Sap4 and anti-Sap60) in one patient with HSN and in three patients with IgAN.

†The number of kidneys investigated varied because of a lack of sufficient tissue for analysis with all antibodies.

properties although a certain degree of antigenic crossreactivity was found. For example, anti-Sap4 reacted well with Sap4 and Sap60 but did not react with Sap22. These data indicate that it is essential to use antisera to different Sap peptides to detect tissue deposition of IgA-BRs.

\section{Detection of the IgA-Binding Region of $M$} Proteins in Kidney Samples from IgAN Patients and Kidney and Skin Samples from HSP

\section{Patients}

Immunohistochemical investigation was performed to determine whether IgA-BRs of the M4, M22, or M60 proteins were deposited in the kidneys of patients with IgAN and HSN, and the skin of patients with HSP, using rabbit antibodies against the three Sap peptides.

In renal biopsies reactivity was seen in the mesangial region and around capillary walls in 17/29 biopsies (10/16 IgAN patients and 7/13 HSN patients, Table 1, Figure 2, A-C). Samples in which staining for an IgA-BR was detected were subject to quantification showing that $59 \%$ of glomeruli exhibited staining for IgA-BRs (Table 1). Labeling with more than one antibody in the same sample occurred in some patients: with all three antibodies in two HSN patients, and with two antibodies (anti-Sap4 and anti-Sap60) in one HSN patient and three IgAN patients.
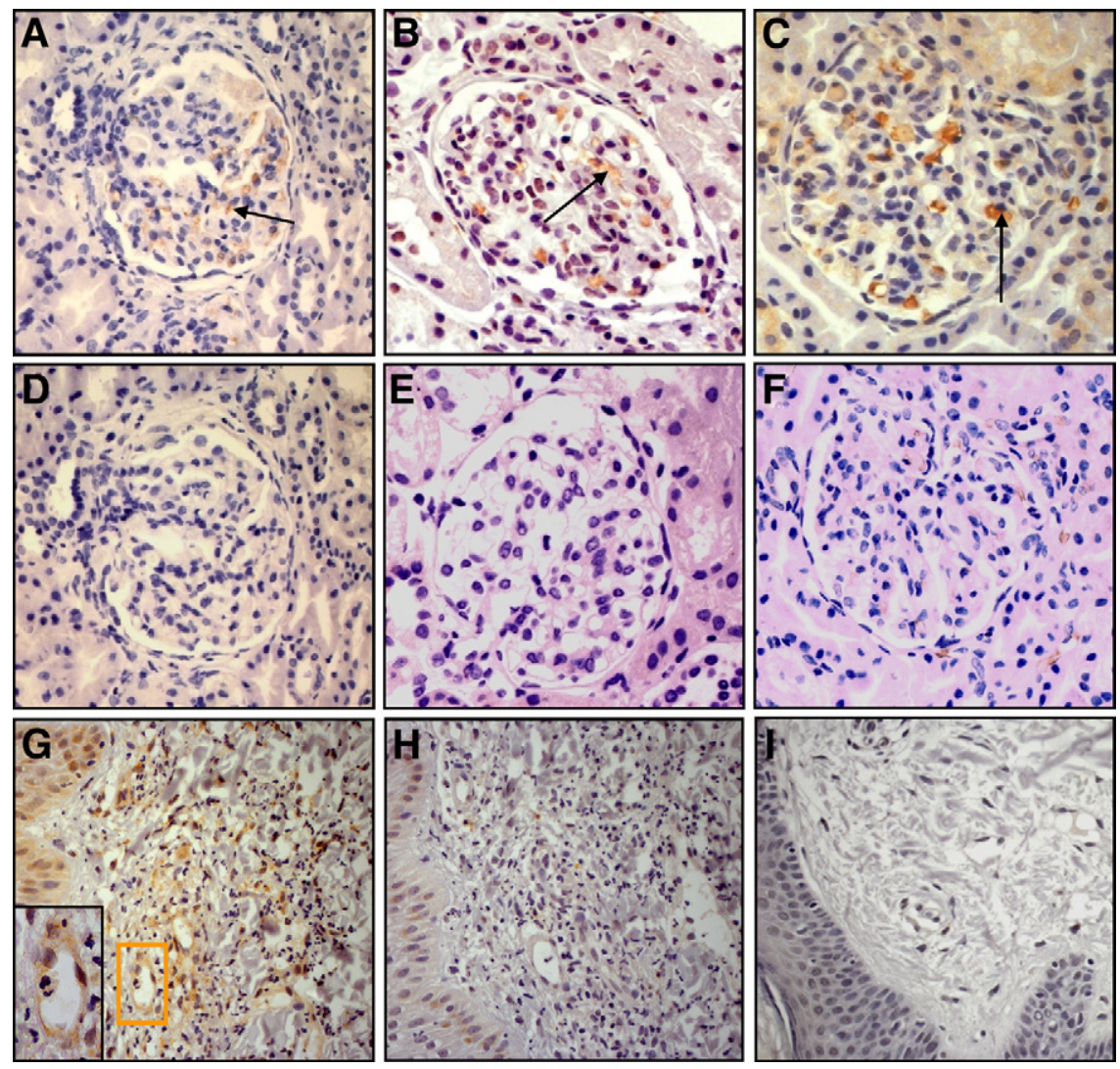

Figure 2. IgA-binding regions of streptococcal M proteins in kidney samples from IgAN patients and kidney and skin samples from HSP patients. A: Renal cortex from a patient with IgAN labeled with anti-Sap60 (ie, antibodies to the IgA-BR of GAS serotype 60). Positive labeling is brown and noted in the mesangial area (see arrow). B: Renal cortex from a HSP patient labeled with anti-Sap4. C: Renal cortex from a HSP patient labeled with anti-Sap60. D: Renal cortex from the same patient as in $\mathbf{A}$. Lack of labeling when the biopsy was incubated with preimmune rabbit serum. E: Normal renal cortex stained with anti-Sap60. F: Renal cortex from the same patient as in C. Specificity demonstrated by lack of labeling when the antibody was preincubated with its specific antigen (Sap60). G-H: Skin sample from a patient with HSP showing typical leukocytoclastic vasculitis with perivascular polymorphonuclear leukocyte and mononuclear cell infiltrates. G: Labeling with anti-Sap22 with pericapillary staining, magnified in the inset. $\mathbf{H}$ : Lack of reactivity when the primary antibody was preincubated with its specific antigen, Sap22, demonstrating specificity. I: Skin sample from a control strained with anti-Sap22. All panels counterstained with hematoxylin and shown at magnification $\times 400$ 

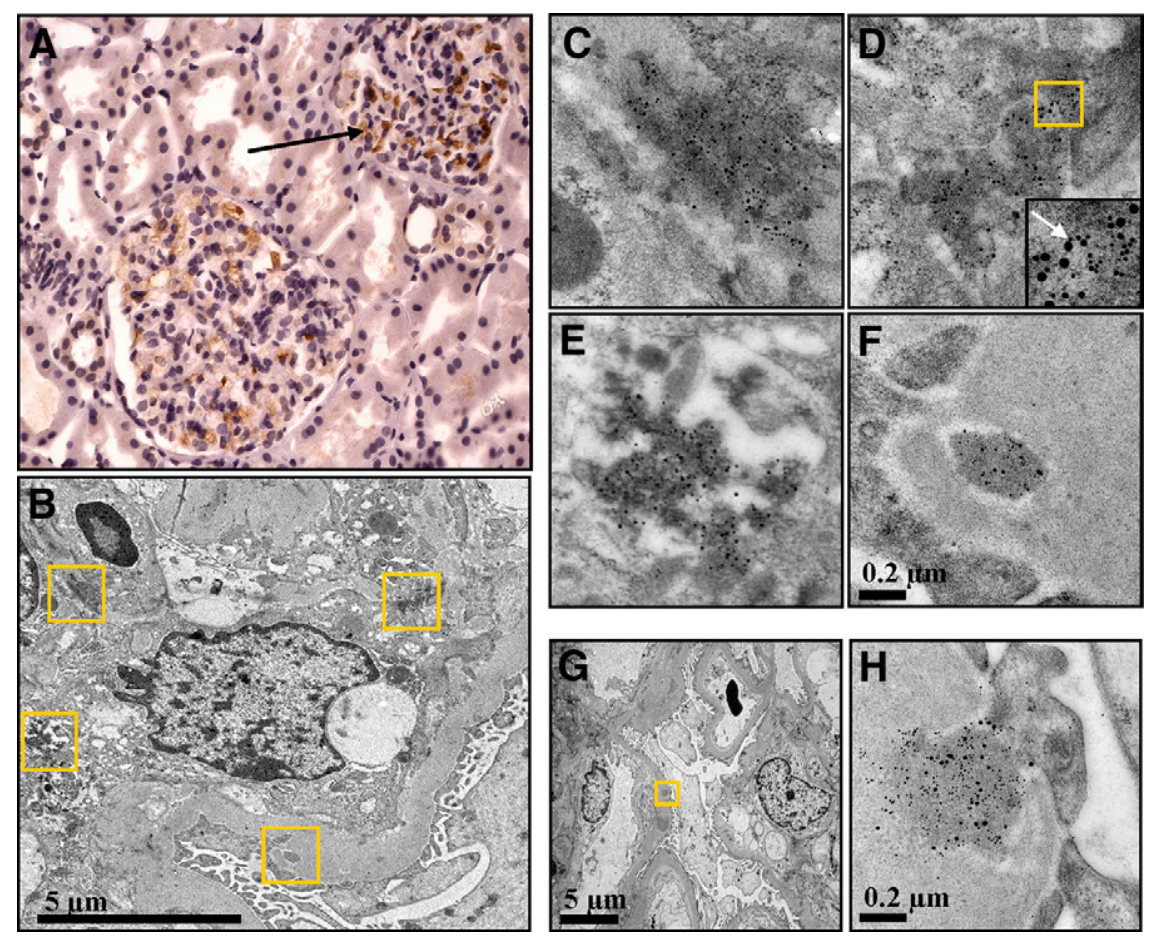

Figure 3. Ultrastructural colocalization of the IgA-binding region of M60 and IgA in the mesangial matrix of a patient with IgAN. A: Immunohistochemistry showing positive labeling for anti-Sap60 in the mesangial area from a patient with IgAN (see arrow pointing to brown labeling, counterstained with hematoxylin, magnification $\times 400$ ). B-H: Immuno-electron microscopy of a renal biopsy from a patient with IgAN Anti-Sap60 was conjugated to 10 -nm gold particles and anti-IgA to 6-nm gold particles. The boxes in panel $\mathbf{B}$ are magnified in panels $\mathbf{C}-\mathbf{F}$ (upper left in C, upper right in D, lower left in $\mathbf{E}$, lower right in F). C-E: Electron-dense deposits of IgA-BR and IgA in the mesangial matrix. The box in panel $\mathbf{D}$ is magnified in the inset in which the arrow points to IgA-BR and IgA in close proximity. F: Electron-dense deposits of IgA-BR and IgA in the GBM. C-F: all at the same magnification. G: Electron-dense deposits in the GBM. H: Magnification of the boxed area in panel G. Colocalization of IgA-BR and IgA is indicated by the proximity $(<30 \mathrm{~nm})$ of the two different gold conjugates.
Control samples of normal renal tissue were negative (Figure 2E).

A GAS strain of serotype M4 was isolated from throat cultures of two patients with IgAN with pharyngitis and macroscopic hematuria. These throat cultures were taken 19 and 31 days before the respective renal biopsies were obtained. The biopsies, taken within two months after the onset of symptoms, exhibited deposits in the mesangial matrix that stained positively with antibodies to the IgA-BR of M4 (data not shown).

To study whether the deposited protein included a larger part of the IgA-binding M protein, we studied renal biopsies from patients that were positive for the IgA-BR of M4 (Table 1). These samples were analyzed for reactivity with antibodies to M4-N, a synthetic peptide derived from the $\mathrm{N}$-terminal hypervariable region of the M4 protein (Figure 1A). Among five kidney biopsies analyzed, three stained positively for M4-N, suggesting that the streptococcal protein deposited in renal tissue may indeed be larger than the IgA-BR (data not shown).

In skin biopsies from patients with HSP perivascular deposits of IgA-BR were found in 4/5 samples (Figure 2G, Table 1). Two patients with HSP (without nephropathy) were positive for IgA-BR from M22, whereas two patients with HSN were positive for IgA-BR from M60. For one of the HSN patients both a skin and a kidney sample were available and positive labeling for the IgA-BR of M60 was demonstrated in each sample. Control samples of normal skin exhibited negative staining (Figure 2l).

Labeling for IgA-BR was found to be specific as it could be abolished by blocking the antibody with the specific antigen (Figure 2, F and $\mathrm{H}$ ). Moreover, tissue that labeled positively with anti-Sap gave negative results when incubated with preimmune rabbit serum (Figure 2D). Kidneys from disease controls did not label for IgA-
BRs (data not shown) with the exception of the renal sample taken from the patient with poststreptococcal glomerulonephritis, which showed positive labeling for IgA-BR of M4 in the mesangial region (data not shown).

\section{Ultrastructural Localization of IgA-Binding Regions of M Proteins and Colocalization with $\lg$ A in Kidney Samples}

The results described above indicated that IgA-BRs were present in many renal samples from patients with IgAN (Figure $3 \mathrm{~A}$ ) and HSN. Ultrastructural investigation of the localization of IgA-BRs was performed on three renal samples. One of these samples was from a patient with IgAN, whose kidney labeled for the IgA-BR of the M60 protein, one sample was from a patient with HSN, whose kidney labeled for the IgA-BR of the M4 protein, and one sample was from the pediatric control whose renal tissue was normal.

Immunogold labeling for the IgA-BR of the M4 or M60 proteins was found in the respective renal tissues from the two patients. Electron-dense deposits were primarily demonstrated in the mesangial matrix but also in the glomerular basement membrane (GBM, Figure 3, B-H for IgA-BR of M60, data not shown for IgA-BR of M4), the subendothelial and subepithelial regions of the GBM, the urinary space (between the GBM and podocyte foot processes), as well as around the capillary walls. No labeling was noted in other renal cells and regions or in the non-tissue background. The IgA-BR clustered in the same areas as $\lg \mathrm{A}$ and colocalization was indicated by the proximity ( $\leq 30 \mathrm{~nm}$ ) of the anti-Sap-antibodies and IgA (Figure 3D). All labeling of IgA-BR colocalized with labeled IgA. 
Table 2. Correlation between Clinical or Pathological Findings and Presence of IgA-BR from M4, M22, and M60 in Renal Biopsies from Patients with IgAN and HSN

\begin{tabular}{cccc}
\hline & $\begin{array}{c}\text { IgA-BR } \\
\text { positive } \\
(n=17)\end{array}$ & $\begin{array}{c}\text { IgA-BR: } \\
\text { negative } \\
(n=12)\end{array}$ & Correlation \\
\hline $\begin{array}{c}\text { Significant } \\
\text { proteinuria* }\end{array}$ & 12 & 7 & $P=0.24 ; \mathrm{ns}$ \\
$\begin{array}{c}\text { Affected renal } \\
\text { function }\end{array}$ & 1 & 2 & $P=0.31 ; \mathrm{ns}$ \\
$\begin{array}{c}\text { Presence of }^{\text {crescents }}{ }^{\ddagger} \\
\text { Mesangial IgG }^{\text {deposits }}\end{array}$ & 11 & 6 & $P=0.22 ; \mathrm{ns}$ \\
$\begin{array}{c}\text { Tubulo-interstitial } \\
\text { involvement }\end{array}$ & 7 & 6 & $P=0.32 ; \mathrm{ns}$ \\
\hline
\end{tabular}

ns indicates not significant.

*Significant proteinuria was arbitrarily defined using one of several clinical laboratory methods as follows: albumin/creatinine-clearance ratio of $>0.7$ (reference value $<0.01$ ); or a urine albumin/creatinine index of $>60 \mathrm{~g} / \mathrm{mol}$ (reference value $<3.8 \mathrm{~g} / \mathrm{mol}$ ); or a urine albumin $>1 \mathrm{~g} / \mathrm{L}$ (reference value $<25 \mathrm{mg} / \mathrm{L}$ ); or an annotation in the patient chart describing heavy proteinuria.

${ }^{\dagger}$ Affected renal function was defined as a $\geq 30 \%$ elevation of serum creatinine above the upper normal limit related to age.

FBiopsy findings determined by light microscopy (crescents, tubulointerstitial involvement) or immunofluorescence (IgG deposits)

Quantification of the immunogold labeling in six different mesangial regions in renal tissue from the IgAN patient showed 163 IgA-BR-related 10-nm gold particles and $468 \mathrm{IgA}$-related 6 -nm gold particles/ $\mu \mathrm{m}^{2}$. Immunogold labeling in five different mesangial regions in renal tissue from the HSN patient showed 164 IgA-BR-related 10-nm gold particles and $401 \mathrm{lgA}$-related 6-nm gold particles $/ \mu \mathrm{m}^{2}$. Reactivity with all three antibodies (anti-Sap4 and anti-Sap60 as well as anti-IgA) was not detected in the control renal tissue (data not shown). Furthermore, labeling for IgA-BR was abolished when the corresponding antibody was preincubated with the antigen (Sap4 or Sap60), and labeling for IgA was abolished when anti-IgA was replaced with an irrelevant mouse $\lg _{1}$ antibody. No labeling was detected when the primary antibodies were omitted (data not shown). These data provide additional evidence for the deposition of IgA-BRs of M proteins in kidneys of patients with IgAN and HSN and show that the IgA-BRs colocalize with IgA.

\section{Lack of Correlation between Clinical or Renal Pathological Features and Detection of IgA-BR in Kidney Samples}

The clinical and renal pathological features found in patients are summarized in Table 2 and further divided according to the detection of IgA-BR in renal tissue. The clinical/pathological manifestations did not show any significant correlation with the presence or absence of IgA-BR in kidney samples. The analysis was, however, limited to studies of the presence of three $M$ proteins. Thus it cannot be ruled out that IgA-BRs from other $M$ proteins may have been present in the tissues. The lack of correlation between the presence or absence of IgA-
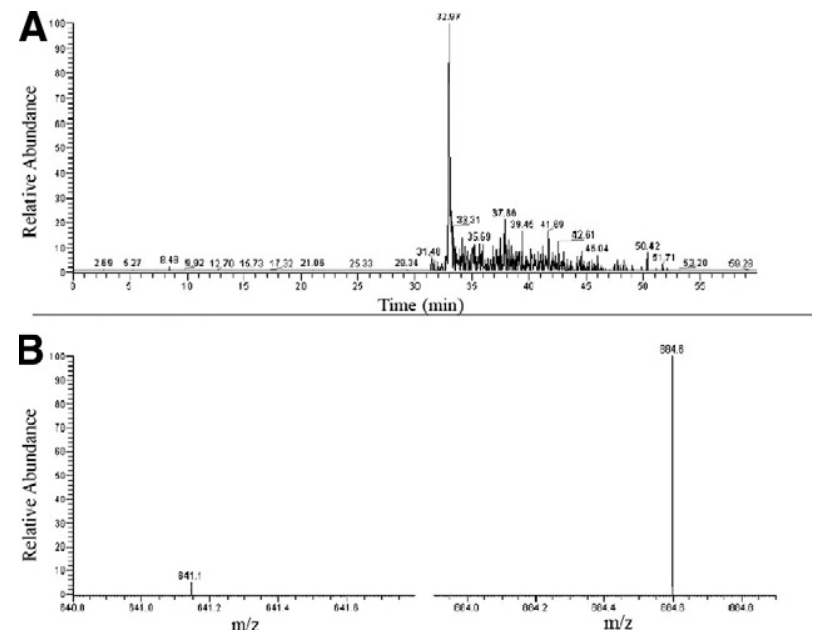

Figure 4. Detection of the IgA-BR from M22 in a skin sample from a patien with HSP. Mass spectrometry analysis of a trypsin-digested skin sample from a patient with HSP (same sample as in Figure 2, G and H). A: In the patient's sample a distinct peak was eluted at 32.97 minutes, the expected retention time for a peptide with the amino acid sequence ALRGENQDLR with a mass/charge $(\mathrm{m} / \mathrm{z})$ ratio of $586.313(\mathrm{M} 2 \mathrm{H}+)$, which is present in the IgA-BR of M22. B: The molecule eluted at 32.97 minutes comprises two daughter ions with a $m / z$ ratio of 641 and 884 in accordance with breakage in the parent peptide after aspargine and aspartic acid.

BRs and clinical/pathological features should therefore be interpreted with caution.

\section{Investigation of Blood Samples for Circulating IgA-BR-IgA Containing Complexes}

Blood samples from patients with positive labeling for IgA-BR in tissue samples were investigated for the presence of complexes containing IgA-BR and IgA-Fc by ELISA. No circulatory complexes between IgA-BR and IgA were detected. In addition, Western blot analysis of patient or normal sera did not detect any protein that reacted with the anti-IgA-BR antibodies. Thus circulating IgA-BR could not be identified by these methods.

\section{Direct Detection of the IgA-BR of M22 in a Skin Sample}

In an attempt to directly demonstrate the presence of an IgA-BR in the tissue of a patient, we analyzed a skin sample from a patient with HSP, found to be positive for the IgA-BR of M22, for whom sufficient material was available for this type of analysis. A trypsin digest of the tissue was analyzed by mass spectrometry. Control extracts were prepared from two samples of normal skin. A distinct peak with an estimated retention time of 32.97 minutes and comprising two ions was present in the patient's sample but not in the controls (Figure 4, A and B). This peak corresponds to a unique sequence present only in the IgA-BR of certain M proteins, including M22. These data indicate that an IgA-BR was present in the patient's tissue. 


\section{Discussion}

Deposition of IgA in glomeruli is the pathological hallmark of IgAN and HSN. Electron microscopy of IgAN typically shows electron dense deposits consisting of IgA in the mesangial matrix, GBM, and glomerular capillary loops. ${ }^{41,42}$ The means by which IgA is trapped in the mesangium is unclear as the human mesangial cell is devoid of the IgA receptor $\mathrm{F}_{\mathrm{c}} \alpha \mathrm{RI}(\mathrm{CD} 89)^{43}$ but may express the transferrin receptor CD71 and the Fc $\alpha / \mu$ receptor, both capable of binding IgA. ${ }^{44,45}$ In the present study we demonstrate the presence of IgA-binding M proteins from GAS in proximity of IgA in the kidneys of many IgAN and HSN patients. The antibodies used to detect IgA-BRs in patient samples were highly specific and the direct detection of the IgA-BR of the M22 protein in the skin of one HSP patient further supported these findings. Thus, the data suggest that IgA-BRs of $\mathrm{M}$ proteins deposit in the kidney during IgAN and HSN and in the skin in HSP, and that these bacterial antigens could contribute to IgA deposition in patient tissues.

IgAN and HSP are frequently preceded by a respiratory infection. The results presented here suggest that a respiratory infection caused by GAS expressing an IgAbinding $\mathrm{M}$ protein may have occurred before symptoms of IgAN or HSP developed and support the view that infections with GAS play an important role in the pathogenesis of IgAN and HSP. ${ }^{10-15}$ Because GAS infections seldom cause bacteremia or septicemia, the presence of $\mathrm{M}$ proteins in tissue is most probably not associated with bacterial invasion. Under certain conditions M proteins are presumably detached from the bacterial wall during bacterial penetration of the mucosal layer in the respiratory tract ${ }^{46,47}$ and enter the systemic circulation. Alternatively, M proteins-or fragments thereof-may be released from phagocytes or antigen-presenting cells that have engulfed whole bacteria. The finding that some kidneys, in which IgA-BR of M4 were deposited, also stained for the N-terminal fragment of M4 (M4-N) suggests that the deposited fragment of $\mathrm{M}$ protein is larger than the IgA-BR.

IgA-BRs of $M$ proteins bind IgA-Fc with high affinity, ${ }^{27,48}$ and immobilized IgA-BR can be used to deplete human serum of IgA. ${ }^{27}$ Thus IgA-BRs detached from bacteria should rapidly bind IgA present in the circulation and form circulating complexes, in which the bacterial protein is bound to the Fc part of IgA. Mesangial entrapment of an IgA-BR would then represent deposition of IgA in complex with an $\mathrm{M}$ protein or an $\mathrm{M}$ protein fragment. Alternatively, IgA-binding $\mathrm{M}$ proteins could first deposit in the kidney, followed by complex formation with IgA from the circulation, but this scenario seems less likely. Although IgA-BRs in complex with IgA were not detected in sera from patients whose kidneys exhibited deposits of IgA-BR, this result does not rule out the possibility of such circulatory complexes occurring earlier on in the course of disease, or at levels not detected by our techniques. A discrepancy between the occurrence of tissue deposits colocalizing with IgA and the lack of circulating complexes may be temporal as the disease may start long before symptoms occur and thus complexes present in tissue may no longer be detectable in serum. It would be intriguing to study the role of GAS in the development of IgAN in vivo, but, because the IgA-BRs of streptococcal $M$ proteins show species specificity for human $\lg A^{48}$ animal models cannot be used for exploring the deposition of IgA-BR containing complexes.

The ultrastructural localization of IgA-BR and IgA follows the pattern described in IgAN. 41,42,49 IgA-containing immune complexes have been detected in mesangium, capillary walls, GBM, and in the urinary space, but it is as yet unclear how immune complexes are deposited. Current models suggest that complexes may be passively trapped in the mesangium, because of the relatively high intraglomerular pressure within the capillaries, which have a large and highly permeable surface. Alternative models hypothesize de novo formation of immune complexes in the mesangium as IgA binds to either a mesangial autoantigen or to a planted antigen. ${ }^{50}$ IgA-BR and IgA were detected not only in the mesangial matrix but also in the GBM and between the GBM and podocytes. The immune complexes are positively charged and the GBM is negatively charged, thus explaining affinity. ${ }^{51}$

Galactose-deficient IgA1 has been implicated in the pathogenesis of IgAN and HSN. ${ }^{6,52-54}$ The mechanism by which the glycosylation deficit occurs is still unknown, but there is evidence that increased production of Th2 cytokines promotes IgA production and causes a defective glycosylation of IgA. ${ }^{55}$ Interestingly, tonsillar lymphocytes derived from patients with IgAN produce underglycosylated $\lg A 1,{ }^{56}$ suggesting that tonsillitis caused by GAS may elicit the release of underglycosylated IgA1 that deposits in kidneys in complex with an IgA-BR. As in vitro studies have indicated that streptococcal M proteins may increase production of Th2 cytokines in lymphocytes from patients with IgAN, ${ }^{57}$ a link can be envisaged between streptococcal infection and defective glycosylation. Thus, there is no contradiction between our data and the hypothesis that underglycosylated IgA plays a key role in IgAN and HSN. ${ }^{7}$

The current investigation concentrated on three IgAbinding $\mathrm{M}$ proteins of different serotypes, but IgA-binding $M$ proteins of several other serotypes also exist. ${ }^{19,23,30}$ Among the three serotypes studied here, M4 and M22 are commonly identified among clinical GAS isolates, ${ }^{29}$ providing an explanation for the presence of the corresponding IgA-BR in some patient samples. It was more surprising that the IgA-BR of the unusual serotype M60 was common among the samples. Possibly, IgAN and HSP are associated with infections caused by GAS strains of unusual serotypes. However, our data show that the IgA-BRs of different M proteins show some antigenic cross-reactivity, suggesting that samples identified as positive for a certain IgA-BR may actually contain the IgA-BR of another M protein. Thus, a biopsy shown to be positive for a certain IgA-BR does not necessarily reflect an infection with GAS of the corresponding serotype. In agreement with this, several biopsies reacted with antiserum to more than one Sap peptide. It follows that biopsies that were negative in our tests may have contained an IgA-BR that was not detected with the antisera 
used. Our data are therefore compatible with the hypothesis that most cases of IgAN and HSP may be associated with tissue deposition of the IgA-BR of a streptococcal M protein. Based on this assumption it is not surprising that the patients' clinical and pathological features did not correlate significantly with the presence or absence of IgA-BR, as even those patients who did not exhibit tissue deposits of IgA-BR may have deposits of IgA-BR from an M serotype not tested for.

Microbiological investigation showed evidence of recent streptococcal infection in some patients. In particular, we isolated two GAS strains of serotype M4 in the throat cultures obtained from newly diagnosed IgAN patients during episodes of IgAN associated with acute pharyngitis, suggesting a causal relationship, as these patients also were positive for the IgA-BR of M4 in their renal biopsies. These results should, however, be interpreted with caution as the precipitating event causing IgAN could have occurred before the throat culture and renal biopsy was obtained. Pharyngitis caused by GAS M4 may thus have precipitated or exacerbated an episode of hematuria in these patients but was not necessarily the initiating event.

All but one control renal tissue stained negatively for the IgA-BR of GAS serotypes M4, 22, or 60 . The one disease control sample that stained positively for the IgA-BR of GAS serotype M4 was taken from a patient with poststreptococcal glomerulonephritis. M4 is one of the known nephritogenic GAS serotypes causing poststreptococcal glomerulonephritis after upper respiratory tract infections, ${ }^{58}$ and the presence of $\mathrm{M}$ proteins in renal biopsies from patients with poststreptococcal glomerulonephritis, primarily in the glomerular basement membrane and in the mesangial region, has previously been suggested. ${ }^{59,60}$ Thus these results are in line with previous observations.

In summary, this study used two independent methods to demonstrate the presence of IgA-BRs of streptococcal $M$ proteins in the kidney and skin of many patients with IgAN and HSP. These data, and the colocalization of IgA-BR and IgA, suggest a pathogenetic role of these $M$ proteins in the etiology of IgAN and HSP, and focus interest on the role of GAS infection in the pathogenesis of these diseases.

\section{Acknowledgments}

We thank Ann-Charlotte Kristoffersson for help with antibody purification, Dr. Margaretha Stålhammar-Carlemalm for help with antibody production and PCR analysis and Dr. Aftab Jasir for PCR analysis of GAS serotypes, Catarina Cramnert for technical assistance with electron microscopy, Professor Per Alm (Department of Pathology) for evaluation of renal biopsies (light and electron microscopy), Professor Peter James and Liselotte Andersson for mass spectrometry expertise, and Assc Professor Peter Höglund for statistical advice.

\section{References}

1. Habib R: Schönlein-Henoch purpura nephritis and IgA-nephropathy Edited by Tisher C BB. Philadelphia, JB Lippincott, 1994, pp. 472-523

2. Donadio JV, Grande JP: IgA nephropathy. N Engl J Med 2002, 347:738-748

3. Tizard EJ, Hamilton-Ayres MJ: Henoch Schönlein purpura. Arch Dis Child Educ Pract Ed 2008, 93:1-8

4. Halling SF, Söderberg MP, Berg UB: Henoch Schönlein nephritis: clinical findings related to renal function and morphology. Pediatr Nephrol 2005, 20:46-51

5. Allen AC, Bailey EM, Brenchley PE, Buck KS, Barratt J, Feehally J: Mesangial IgA1 in IgA nephropathy exhibits aberrant O-glycosylation: observations in three patients. Kidney Int 2001, 60:969-973

6. Novak J, Moldoveanu Z, Renfrow MB, Yanagihara T, Suzuki H, Raska M, Hall S, Brown R, Huang WQ, Goepfert A, Kilian M, Poulsen K, Tomana M, Wyatt RJ, Julian BA, Mestecky J: IgA nephropathy and Henoch-Schoenlein purpura nephritis: aberrant glycosylation of IgA1, formation of IgA1-containing immune complexes, and activation of mesangial cells. Contrib Nephrol 2007, 157:134-138

7. Lau KK, Suzuki H, Novak J, Wyatt RJ: Pathogenesis of HenochSchönlein purpura nephritis, Pediatr Nephrol 2010, 25:19-26

8. Suzuki H, Fan R, Zhang Z, Brown R, Hall S, Julian BA, Chatham WW Suzuki Y, Wyatt RJ, Moldoveanu Z, Lee JY, Robinson J, Tomana M, Tomino Y, Mestecky J, Novak J: Aberrantly glycosylated IgA1 in IgA nephropathy patients is recognized by IgG antibodies with restricted heterogeneity. J Clin Invest 2009, 119:1668-1677

9. Allen AC, Feehally J: IgA1 glycosylation and the pathogenesis of $\lg A$ nephropathy. Am J Kidney Dis 2000, 35:551-556

10. al-Sheyyab M, Batieha A, el-Shanti H, Daoud A: Henoch-Schönlein purpura and streptococcal infection: a prospective case-control study. Ann Trop Paediatr 1999, 19:253-255

11. Eisenstein EM, Navon-Elkan P: Acute rheumatic fever associated with Henoch-Schönlein purpura: report of three cases and review of the literature. Acta Paediatr 2002, 91:1265-1267

12. Masuda M, Nakanishi K, Yoshizawa N, lijima K, Yoshikawa N: Group A streptococcal antigen in the glomeruli of children with HenochSchönlein nephritis. Am J Kidney Dis 2003, 41:366-370

13. Kukuminato $Y$, Hamamoto $M$, Kataura A: Role of serum antibodies to streptococci in patients with IgA nephropathy. Acta Otolaryngol Suppl 1993, 508:6-10

14. Nakatsuka K: Serum anti-streptococcal IgA. IgG and IgM antibodies in IgA-associated diseases, Acta Paediatr Jpn 1993, 35:118-123

15. Kikuchi Y, Yoshizawa N, Oda T, Imakiire T, Suzuki S, Miura S: Streptococcal origin of a case of Henoch-Schoenlein purpura nephritis. Clin Nephrol 2006, 65:124-128

16. Suzuki S, Nakatomi Y, Sato H, Tsukada H, Arakawa M: Haemophilus parainfluenzae antigen and antibody in renal biopsy samples and serum of patients with IgA nephropathy, Lancet 1994, 343:12-16

17. Koyama A, Sharmin S, Sakurai H, Shimizu Y, Hirayama K, Usui J, Nagata M, Yoh K, Yamagata K, Muro K, Kobayashi M, Ohtani K, Shimizu T: Staphylococcus aureus cell envelope antigen is a new candidate for the induction of IgA nephropathy, Kidney Int 2004, 66:121-132

18. Takahashi A, Kawasaki Y, Yoshida K, Mochizuki K, Isome M, Honzumi K, Nozawa R, Suzuki S, Hosoya M, Suzuki J, Suzuki H: Detection of enteroviruses in renal biopsies from patients with immunoglobulin A nephropathy. Pediatr Nephrol 2005, 20:1578-1582

19. Lindahl G, Stenberg L: Binding of IgA and/or IgG is a common property among clinical isolates of group A streptococci. Epidemiol Infect 1990, 105:87-93

20. Frithz E, Heden LO, Lindahl G: Extensive sequence homology between IgA receptor and $\mathrm{M}$ proteins in Streptococcus pyogenes. Mol Microbiol 1989, 3:1111-1119

21. Bessen DE, Fischetti VA: Nucleotide sequences of two adjacent $M$ or M-like protein genes of group A streptococci: different RNA transcript levels and identification of a unique immunoglobulin A-binding protein. Infect Immun 1992, 60:124-135

22. Johnsson E, Andersson G, Lindahl G, Heden LO: Identification of the IgA-binding region in streptococcal protein. Arp. J Immunol 1994, 153:3557-3564

23. Bessen DE: Localization of immunoglobulin A-binding sites within $M$ or M-like proteins of group A streptococci. Infect Immun 1994 . 62:1968-1974 
24. Fischetti VA: Streptococcal M protein: molecular design and biological behavior. Clin Microbiol Rev 1989, 2:285-314

25. Facklam RF, Martin DR, Lovgren M, Johnson DR, Efstratiou A, Thompson TA, Gowan S, Kriz P, Tyrrell GJ, Kaplan E, Beall B: Extension of the Lancefield classification for group A streptococci by addition of 22 new $M$ protein gene sequence types from clinical isolates: emm103 to emm124. Clin Infect Dis 2002, 34:28-38

26. Carlsson F, Berggård K, Stålhammar-Carlemalm M, Lindahl G: Evasion of phagocytosis through cooperation between two ligand-binding regions in Streptococcus pyogenes M protein. J Exp Med 2003, 198:1057-1068

27. Sandin C, Linse S, Areschoug T, Woof JM, Reinholdt J, Lindahl G: Isolation and detection of human IgA using a streptococcal IgAbinding peptide. J Immunol 2002, 169:1357-1364

28. Johnsson E, Areschoug T, Mestecky J, Lindahl G: An IgA-binding peptide derived from a streptococcal surface protein. J Biol Chem 1999, 274:14521-14524

29. Colman G, Tanna A, Efstratiou A, Gaworzewska ET: The serotypes of Streptococcus pyogenes present in Britain during 1980-1990 and their association with disease. J Med Microbiol 1993, 39:165-178

30. Stenberg L, O'Toole P, Lindahl G: Many group A streptococcal strains express two different immunoglobulin-binding proteins, encoded by closely linked genes: characterization of the proteins expressed by four strains of different M-type. Mol Microbiol 1992, 6:1185-1194

31. Stenberg L, O'Toole PW, Mestecky J, Lindahl G: Molecular characterization of protein Sir, a streptococcal cell surface protein that binds both immunoglobulin A and immunoglobulin G. J Biol Chem 1994, 269:13458-13464

32. Morfeldt $E$, Berggård $K$, Persson J, Drakenberg $T$, Johnsson $E$, Lindahl E, Linse S, Lindahl G: Isolated hypervariable regions derived from streptococcal M proteins specifically bind human C4b-binding protein: implications for antigenic variation. J Immunol 2001, 167: 3870-3877

33. Mills JA, Michel BA, Bloch DA, Calabrese LH, Hunder GG, Arend WP Edworthy SM, Fauci AS, Leavitt RY, Lie JT, et al.: The American College of Rheumatology 1990 criteria for the classification of Henoch-Schönlein purpura. Arthritis Rheum 1990, 33:1114-1121

34. Beall B, Facklam R, Thompson T: Sequencing emm-specific PCR products for routine and accurate typing of group A streptococci. J Clin Microbiol 1996, 34:953-958

35. Manea M, Tati R, Karlsson J, Bekassy ZD, Karpman D: Biologically active ADAMTS13 is expressed in renal tubular epithelial cells. Pediatr Nephrol 2010, 25:87-96.

36. Roth J: Post-embedding cytochemistry with gold-labelled reagents: a review. J Microsc 1986, 143:125-137

37. Bengtson SH, Phagoo SB, Norrby-Teglund A, Påhlman L, Mörgelin M, Zuraw BL, Leeb-Lundberg LM, Herwald H: Kinin receptor expression during Staphylococcus aureus infection. Blood 2006, 108:2055-2063

38. Kim JH, Cramer L, Mueller H, Wilson B, Vilen BJ: Independent trafficking of Ig-alpha/lg-beta and mu-heavy chain is facilitated by dissociation of the B cell antigen receptor complex. J Immunol 2005, 175:147-154

39. Sarma VR, Davies DR, Labaw LW, Silverton EW, Terry WD: Crystal structure of an immunoglobulin molecule by $x$-ray diffraction and electron microscopy. Cold Spring Harb Symp Quant Biol 1972, 36:413-419

40. Picotti P, Lam H, Campbell D, Deutsch EW, Mirzaei H, Ranish J, Domon B, Aebersold R: A database of mass spectrometric assays for the yeast proteome. Nat Methods 2008, 5:913-914

41. Dysart NK Jr, Sisson S, Vernier RL: Immunoelectron microscopy of IgA nephropathy. Clin Immunol Immunopathol 1983, 29:254-270

42. Yoshiara S, Yoshikawa N. Matsuo T: Immunoelectron microscopic study of childhood IgA nephropathy and Henoch-Schönlein nephritis. Virchows Arch A Pathol Anat Histopathol 1987, 412:95-102

43. Westerhuis R, Van Zandbergen G, Verhagen NA, Klar-Mohamad N, Daha MR, van Kooten C: Human mesangial cells in culture and in kidney sections fail to express Fc alpha receptor (CD89). J Am Soc Nephrol 1999, 10:770-778

44. Moura IC, Centelles MN, Arcos-Fajardo M, Malheiros DM, Collawn JF, Cooper MD, Monteiro RC: Identification of the transferrin receptor as a novel immunoglobulin (Ig)A1 receptor and its enhanced expression on mesangial cells in IgA nephropathy. J Exp Med 2001, 194: 417-425

45. McDonald KJ, Cameron AJ, Allen JM, Jardine AG: Expression of Fo alpha/mu receptor by human mesangial cells: a candidate receptor for immune complex deposition in IgA nephropathy. Biochem Biophys Res Commun 2002, 290:438-442

46. Herwald H, Cramer H, Mörgelin M, Russell W, Sollenberg U, NorrbyTeglund A, Flodgaard $\mathrm{H}$, Lindbom L, Björck L: M protein, a classical bacterial virulence determinant, forms complexes with fibrinogen that induce vascular leakage. Cell 2004, 116:367-379

47. Berge A, Björck L: Streptococcal cysteine proteinase releases biologically active fragments of streptococcal surface proteins. J Biol Chem 1995, 270:9862-9867

48. Åkerström B, Lindqvist A, Lindahl G: Binding properties of protein Arp, a bacterial IgA-receptor. Mol Immunol 1991, 28:349-357

49. Navas-Palacios JJ, Gutierrez-Millet V, Usera-Sarrage G, Garzon-Martin A: IgA nephropathy: an ultrastructural study. Ultrastruct Pathol 1981, 2:151-161

50. Smith AC, Feehally J: New insights into the pathogenesis of IgA nephropathy. Pathogenesis of IgA nephropathy, Springer Semin Immunopathol 2003, 24:477-493

51. Nangaku M, Couser WG: Mechanisms of immune-deposit formation and the mediation of immune renal injury. Clin Exp Nephrol 2005, 9:183-191

52. Barratt J, Smith AC, Molyneux K, Feehally J: Immunopathogenesis of IgAN. Semin Immunopathol 2007, 29:427-443

53. Mestecky J, Tomana M, Moldoveanu Z, Julian BA, Suzuki $H$, Matousovic K, Renfrow MB, Novak L, Wyatt RJ, Novak J: Role of aberrant glycosylation of IgA1 molecules in the pathogenesis of IgA nephropathy. Kidney Blood Press Res 2008, 31:29-37

54. Allen AC, Willis FR, Beattie TJ, Feehally J: Abnormal IgA glycosylation in Henoch-Schönlein purpura restricted to patients with clinical nephritis. Nephrol Dial Transplant 1998, 13:930-934

55. Chintalacharuvu SR, Nagy NU, Sigmund N, Nedrud JG, Amm ME, Emancipator SN: T cell cytokines determine the severity of experimental IgA nephropathy by regulating IgA glycosylation. Clin Exp Immunol 2001, 126:326-333

56. Horie A, Hiki Y, Odani H, Yasuda Y, Takahashi M, Kato M, Iwase H, Kobayashi Y, Nakashima I, Maeda K: IgA1 molecules produced by tonsillar lymphocytes are under-O-glycosylated in IgA nephropathy. Am J Kidney Dis 2003, 42:486-496

57. Nishikawa $Y$, Shibata R, Ozono $Y$, Ichinose H, Miyazaki M, Harada T, Kohno S: Streptococcal M protein enhances TGF-beta production and increases surface IgA-positive B cells in vitro in IgA nephropathy. Nephrol Dial Transplant 2000, 15:772-777

58. Cunningham MW: Pathogenesis of group A streptococcal infections. Clin Microbiol Rev 2000, 13:470-511

59. Treser G, Semar M, Ty A, Agel I, Franklin MA, Lange K: Partial characterization of antigenic streptococcal plasma membrane components in acute glomerulonephritis. J Clin Invest 1970, 49:762-768

60. Rodriguez-Iturbe B, Batsford S: Pathogenesis of poststreptococcal glomerulonephritis a century after Clemens von Pirquet. Kidney Int 2007, 71:1094-1104 